\section{PEPTIDE EXTRACTS FROM TEMPEH PROTECT AGAINST PHOTOAGING VIA DOWN- REGULATING MATRIX METALLOPROTEINASE-3 GENE EXPRESSION}

Steffanus Pranoto Hallisa, Yantib*, Maggy Thenawidjaja Suhartonoc, Soegianto Alid

aGraduate School of Biotechnology, Atma Jaya Catholic University of Indonesia, 12930, Jakarta, Indonesia

bDepartment of Food Technology, Faculty of Biotechnology, Atma Jaya Catholic University of Indonesia, 15345, Tangerang, Indonesia cDepartment of Food Science and Technology, Faculty of Agricultural Technology, Bogor Agricultural University, 16680, Bogor, Indonesia

dFaculty of Medicine and Health Sciences, Atma Jaya Catholic University of Indonesia, 14440, Jakarta, Indonesia
Article history

Received

1 July 2019

Received in revised form

10 November 2019

Accepted

17 November 2019

Published online

25 December 2019

*Corresponding author yanti@atmajaya.ac.id

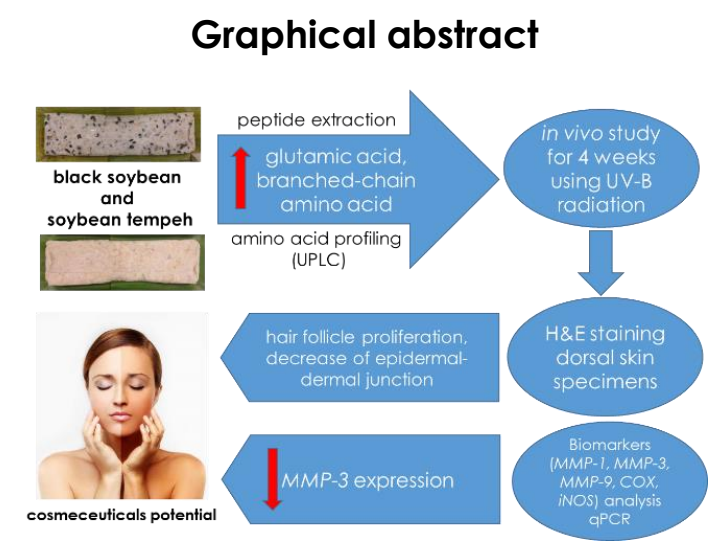

\begin{abstract}
Photoaging damages skin tissue via activation of matrix metalloproteinases (MMPs) and MMP-3 induces activation of MMP-1 and 9. Tempeh is made from fermented soybean in Indonesia and has been known for its high protein content. This study was aimed to investigate the effectiveness of peptide extracts from tempeh against photoaging at gene level in UVBtreated mice. Peptide was extracted from soybean and black soybean tempeh, and identified for its amino acid profiling. Photoaging model was made by gradient UVB exposure to seven groups of mice for 4 weeks. Mice were supplemented with 100 and $300 \mathrm{mg} / \mathrm{kg}$ body weight dosages of peptide extracts from soybean and black soybean tempeh. Dorsal skin tissue was collected for histology staining and quantitative polymerase chain reaction (qPCR). This present study found that both tempeh peptide extracts were rich in glutamic acid and branched-chain amino acids. Histology staining showed that tempeh protected mice skin from photoaging. At 100 and $300 \mathrm{mg} / \mathrm{kg}$, both tempeh peptide extracts significantly attenuated MMP-3gene expression that lead to the decrease level of MMP-1 and MMP-9 gene expression. These results suggest that supplementation of both tempeh peptide extracts may possess antiphotoaging effect via altering MMP-3 gene expression in UVB-treated mice.
\end{abstract}

Keywords: Tempeh, peptide extracts, anti-photoaging activity, UVBinduced mice, MMP-3

(C) 2020 Penerbit UTM Press. All rights reserved

\subsection{INTRODUCTION}

Photoaging is the phenomenon of skin inflammation and connective tissue damage induced by UV radiation [1]. Among the UV spectrums, UVB (290-320 $\mathrm{nm}$ ) is the main cause of photoaging. UVB spectrum may penetrate into the dermal layer of skin tissue [2]. The penetration induces oxidative stress and increase 
the production of reactive oxygen species (ROS). ROS will activate the mechanism of DNA damage and inflammation genes, including cyclooxygenase2 (COX-2) and inducible nitric oxide synthase (iNOS). Several enzymes, such as collagen degrading-matrix metalloproteinase (MMP) 1, MMP-2 and MMP-9 are activated along this reaction [3]. This phenomenon, also known as dermatoheliosis, has several esthetical effects, such as skin pigmentation and wrinkle [4].

The cumulative effect of photoaging may lead into major problems of health, initiation of tumor, and increase skin cancer risk $[5,6]$. Many researches have been conducted to reduce the skin inflammation and formulating skin protection. Recently, antiphotoaging supplement extracted from Pangasius hypophthalamus was developed [7]. This supplement contains tripeptide collagen which has potential activity to enhance the skin elasticity. It is because of potential peptide which acts as antioxidant. Thus, ROS can be reduced significantly. Moreover, oral supplementation of the peptide reduces formation of the abnormal elastic fiber.

Current trends in cosmeceuticals bring out the potential fermented product as skin whitening and rejuvenating. The most popular fermented product that has been used widely is kefir, a fermented milk product. A total of 236 isolated peptides have been identified from kefir and 16 of them showed the potency as bioactive compound that role as antiaging agents [8]. Tempeh is one of potential fermented product from Indonesia made from soybean. The fermentation of soybean during tempeh production generates peptides and amino acids. Essential amino acids weight generated from this process was $1.70 \mathrm{~g} / 100 \mathrm{~g}$ dry matter, respectively [7]. Moreover, tempeh has potency as antiphotoaging agents, because it mainly contained of peptide, oligopeptide, and other nitrogen derivative compounds. It also contains many phytochemicals and isoflavone, such as genistein and daidzein [9]. However, screening of tempeh as potential antiphotoaging agents is lacking. The purpose of this study was to investigate soybean and black soybean tempeh peptides effectiveness to reduce photoaging in mice using matrix metalloproteinases and inflammation biomarkers.

\subsection{METHODOLOGY}

\subsection{Materials}

Natrium hydroxide $(\mathrm{NaOH})$ were provided by Sigma (St. Louis, Missouri, USA). All the water used had been distilled to aquadestusing GFL Water Distillation Unit 2008 (GFL, Burgwedel, Germany). The RNA extraction reagent GENEzolTM was purchased from Geneaid (New Taipei City, Taiwan) while CDNA synthesis reagent ReverTra Ace ${ }^{\circledR}$ QPCR RT Master Mix with gDNA remover and THUNDERBIRD $\circledast$ SYBR $\AA$ GPCR Mix were provided by Toyobo (Osaka, Japan). All of the primers were synthesized by Integrated DNA Technologies (Singapore).

\subsection{Preparation of Peptide Extracts from Soybean and Black Soybean Tempeh}

Soybean and black soybean tempeh were collected from Tjah Dampit, a traditional organic tempeh industry in Yogyakarta (Indonesia). A total of $250 \mathrm{~g}$ samples were cut and freeze-dried using Martin Christ Alpha 1-2 LDPlus Freeze Dryer (Christ, Osterode, Germany) for 40 hours until become powder. Peptide extraction was done according to previous study with modifications in hydrolytic enzyme [10]. Tempeh powder was diluted with aquadest. The $\mathrm{pH}$ was adjusted to 8.0 using $2.5 \mathrm{M} \mathrm{NaOH}$. Enzyplex® powder was added until the concentration reach $1 \% \mathrm{w} / \mathrm{v}$ in the mixture. The mixture was incubated in WiseBath waterbath shaker (Daihan, Wonju, South Korea) at 75 rpm in $37^{\circ} \mathrm{C}$ for 30 minutes. After the incubation, the mixture was centrifuged at $4{ }^{\circ} \mathrm{C}, 3000 \times \mathrm{g}$ for 30 minutes. The supernatant was filtered and dried by lyophilization using freeze dryer. The samples were stored at $-20{ }^{\circ} \mathrm{C}$ for further analysis. Verification of peptide was done using sodium dodecyl sulfatepolyacrylamide gel electrophoresis with $15 \%$ sample and $18 \%$ gel concentration. Peptide molecular weight was determined based on Spectra ${ }^{\top M}$ Multicolor Low Range Protein Ladder (ThermoFisher, Massachusetts, USA) as marker. Tempeh peptide extracts had molecular weights of 11.2 and $12.6 \mathrm{kDa}$ (data not shown).

2.3 Identification of Amino Acid Composition in Peptide Extracts Using Ultra Performance Liquid Chromatography

The identification procedure was performed according to Acquity UPLC H-Class and $\mathrm{H}$-Class Bio Amino Acid Analysis System Guide revision B developed by Waters (Milford, MA, USA). A standard solution of mixed amino acid was homogenized with internal standard AABA (1:1) in $920 \mu \mathrm{L}$ aquabidest. The solution was added with ACC-Q-Fluor Borate and reagent fluor $A$. After incubation for 1 minute at room temperature, the solution was incubated at $55^{\circ} \mathrm{C}$ for 10 minutes.

Derivatization method of peptide for UPLC and elution condition were performed as described previously [11]. Briefly, peptide samples $(0.1 \mathrm{~g})$ were hydrolyzed with $1 \mathrm{~mL} 6 \mathrm{~N} \mathrm{HCl}(1: 10)$ at $110^{\circ} \mathrm{C}$ for 22 hours. The samples were diluted with aquabidest and then filtered through $0.45 \mu \mathrm{m}$ syringe filter (Waters, Milford, MA, USA). Acc-Q-Fluor Borate and reagent fluor $A$ were added to the solution and incubated for 1 minute at room temperature before incubated at $55{ }^{\circ} \mathrm{C}$ for 10 minutes. The UPLC method was developed for the identification of amino acid composition using AccQ-Tag Ultra C18 Column (2.1 x $100 \mathrm{~mm}$ ) (Waters, Milford, MA, USA). The flow rate was set at $0.7 \mathrm{~mL} / \mathrm{min}$, injection volume was $1 \mu \mathrm{L}$, column temperature was set at $49^{\circ} \mathrm{C}$ and detection 
was carried out with photodiode array detector at $260 \mathrm{~nm}$. The mobile phase consisted of (A) acetonitrile (100\% AccQ Tag Ultra Elvent A) and (B) formic acid (90:10 HPLC-grade water water:AcCQ Tag Ultra Elvent B). This system used gradient elution mode as follows: 0-0.54 $\mathrm{min}, 0.1 \% \mathrm{~A}-99.9 \% \mathrm{~B} ; 5.74 \mathrm{~min}$, 9.1\%A-90.9\%B; $7.74 \mathrm{~min}, 21.2 \% \mathrm{~A}-78.8 \% \mathrm{~B} ; 8.04 \mathrm{~min}$ $59.6 \% \mathrm{~A}-40.4 \% \mathrm{~B} ; 8.70-10 \mathrm{~min}, 99.9 \% \mathrm{~A}-0.1 \% \mathrm{~B}$.

\subsection{Animals Experiment}

The in vivo study was conducted at VStem Animal Facility (Bogor, Indonesia) and the protocol was approved by the Animal Welfare Supervision Commission and Use of Research Animals (No. VS.0217-IR). A total of 28 male Deutschland, Denken, and Yonken (ddY) mice aged 6 weeks with body weight $25 \pm 1$ g were divided into seven groups, each contained four mice; negative control (NC) and positive control (PC) without supplementation, peptide control (SP) supplemented with commercial cosmeceuticals, the remaining four supplemented with peptide extracts for 28 days (Table 1). The mice were adapted to the laboratory environment 7 days prior to the treatment and fed with standard diet. The dorsal areas of the mice were shaved to give hairless condition. The mice were housed in group in sanitary ventilated animal rooms under controlled temperature $25 \pm 1^{\circ} \mathrm{C}, 60 \%$ relative humidity, and fed with standard feed. Photoaging mice modeling were conducted according to previous studies with some modification [7, 12]. Briefly, UVB was irradiated every two days for 4 weeks gradually: $100 \mathrm{~mJ} / \mathrm{cm}^{2}$ for 10 minutes in week-1, $150 \mathrm{~mJ} / \mathrm{cm}^{2}$ for 15 minutes in week-2 and $200 \mathrm{~mJ} / \mathrm{cm}^{2}$ for 20 minutes in week-3 and 4. The mice were sacrificed at day 29 and the dorsal skins were collected for histology staining and QPCR.

Table 1 Experimental supplementation design of photoaging mice model

\begin{tabular}{lll}
\hline Group & $\begin{array}{l}\text { UVB } \\
\text { Radiation }\end{array}$ & Sample \\
\hline Negative control (NC) & - & - \\
Positive control (PC) & + & - \\
Standard peptide (SP) & + & $\begin{array}{l}2 \% \mathrm{~W} / \mathrm{V} \text { commercial } \\
\text { cosmeceuticals }\end{array}$ \\
PP 100 & + & $\begin{array}{l}100 \mathrm{mg} / \mathrm{kgs} \text { body weight } \\
\text { soybean tempeh peptide }\end{array}$ \\
PP 300 & + & $\begin{array}{l}300 \mathrm{mg} / \mathrm{kgs} \text { body weight } \\
\text { soybean tempeh peptide } \\
100 \mathrm{mg} / \mathrm{kgs} \text { body weight } \\
\text { black soybean tempeh } \\
\text { peptide } \\
300 \mathrm{mg} / \mathrm{kgs} \text { body weight } \\
\text { black soybean tempeh } \\
\text { peptide }\end{array}$ \\
& + &
\end{tabular}

\subsection{Histology Staining of Skin Tissues}

The dorsal skin specimens (approximately $1 \mathrm{~cm}^{2}$ ) were fixed in $4 \%$ buffered neutral formalin for at least
$24 \mathrm{~h}$ and stained using hematoxylin and eosin method [13]. Skin histology changes, including epidermis thickening and formation of dermal junction were observed by light microscopy at 200x and 400x magnification using nominal scoring method [14].

2.6 Determination of Photoaging-related Genes Expressions Using Quantitative Polymerase Chain Reaction

Analysis of GPCR was used to measure the expressions of matrix metalloproteinase-1 (MMP-1), MMP-3, MMP-9, cyclooxygenase-2 (COX-2) and inducible nitric oxide synthase (iNOS) genes. RNA from the dorsal skin was isolated using GENEzolTM according to the manufacturer's protocols. CDNA was synthesized using ReverTra Ace $\AA$ qPCR RT Master Mix with gDNA remover according to the protocols. qRT-PCR was carried out using THUNDERBIRD® SYBRß qPCR Mix performed on iQ5 Multicolor Real Time PCR (BioRad, California, USA) with beta-actin as a reference gene. Primer sequences were listed in (Table 2).

Table 2 Oligonucleotide primer sequences

\begin{tabular}{|c|c|c|c|}
\hline Gene & Forward & Reverse & $\begin{array}{l}\text { Size } \\
\text { (bp) }\end{array}$ \\
\hline$M M P-1$ a) & $\begin{array}{l}\text { GTTGGAGCAGG } \\
\text { CAGGAAGGAG }\end{array}$ & $\begin{array}{l}\text { TTGCCTCAGCTTT } \\
\text { TCAGCCAT }\end{array}$ & 245 \\
\hline MMP-3 b) & $\begin{array}{l}\text { GGCGCAAATCT } \\
\text { CTCAGGACT }\end{array}$ & $\begin{array}{l}\text { TTCTTCACGGTTG } \\
\text { CAGGGAG }\end{array}$ & 217 \\
\hline MMP-9c) & $\begin{array}{l}\text { AAAGGCAGCG } \\
\text { TTAGCCAGAA }\end{array}$ & $\begin{array}{l}\text { TTGGAATCGAC } \\
\text { CCACGTCTG }\end{array}$ & 362 \\
\hline $\operatorname{COX}-2$ d) & $\begin{array}{l}\text { CTTCGGGAGCA } \\
\text { CAACAGAGT }\end{array}$ & $\begin{array}{l}\text { GGG } \\
\text { TGAT }\end{array}$ & 252 \\
\hline iNOSel & $\begin{array}{l}\text { TGCCAGGGTCA } \\
\text { CAACTTTACA }\end{array}$ & $\begin{array}{l}\text { TGAGAACAGCA } \\
\text { CAAGGGGTT }\end{array}$ & 335 \\
\hline$\beta$-actin f) & $\begin{array}{l}\text { AGGGAAATCGT } \\
\text { GCGTGACAT }\end{array}$ & $\begin{array}{l}\text { ACTGTGTTGGCA } \\
\text { TAGAGGTC }\end{array}$ & 278 \\
\hline \multicolumn{4}{|c|}{$\begin{array}{l}\text { a) Matrix metalloproteinase-1; b) Matrix metalloproteinase-3; c) Matrix } \\
\text { metalloproteinase-9; d) Cyclooxygenase-2; e) Inducible nitric oxide } \\
\text { synthase; f) Beta-actin. }\end{array}$} \\
\hline \multicolumn{4}{|c|}{ 2.7 Statistical Analysis } \\
\hline \multicolumn{4}{|c|}{$\begin{array}{l}\text { All data are presented as the means } \pm \text { standard } \\
\text { deviation from three independent experiments. Data } \\
\text { were evaluated using the one way-analysis of } \\
\text { variance test and Tukey post-test using GraphPad } \\
\text { Prism } 5 \text { (GraphPad Software, Inc., La Jolla, USA). The } \\
\text { difference between the fold change (double delta } \\
\text { CT) means was considered significant when P } \leq 0.05 \text {. }\end{array}$} \\
\hline
\end{tabular}

\subsection{RESULTS AND DISCUSSION}

3.1 Amino Acid Composition in Peptideextracts from Soybean and Black Soybean Tempeh

Peptide cosmeceuticals has been developed from many resources, mostly derived from fish collagen 
such as from silver carp and pangas or tilapia gelatin peptides $[7,15,16]$. Fermented barley and soybean mixturesare also promising anti-photoaging agents [9]. In this study, we discovered the potential peptides derived from tempeh, traditional fermented soybean cake from Indonesia, as anti-photoaging and cosmeceuticals agents. The yields of peptide extracts were $7 \% \mathrm{w} / \mathrm{w}$ for soybean tempeh and $8.3 \%$ $\mathrm{w} / \mathrm{w}$ for black soybean tempeh.

To qualify as a cosmeceutical agent, a peptide should possess one of the following four activities: antioxidant, tyrosinase inhibitor, MMP inhibitor, and anti-inflammatory [17]. Since photoaging activates ROS, the antioxidant activities of a peptide will diminish the ROS to act as anti-aging and increase photo-protective effects [18]. Similarly, photoaging damages the skin by increase MMP activation to promote collagen degradation [19]. Thus, photoaging skin develops wrinkle due to loss of collagen. Therefore, MMP inhibitor activity of peptide could represent anti-wrinkle effect which inhibit collagen degradation [20, 21].

Nonetheless, tyrosinase inhibitor activity frequently associated with whitening effect and antiinflammatory also corresponded with skin soothing effect [22, 23]. These activities are driven by bioactive peptides consisting specific amino acid sequences derived from specific enzymes [17]. Moreover, the collagen pentapeptide (Lys-Thr-ThrLys-Ser, KTTKS), which was reported topromote the production of extracellular matrix and $f$ type I collagen, could permeate the skin effectively, hence it is potential to be used as a cosmeceutical agent [24].

The amino acid compositions in peptide extracts of soybean and black soybean tempeh were quantified based on multiple amino acid standards. More than $20 \%$ of the amino acids identified in both peptide extracts were L-glutamic acid. In soybean tempeh peptide extract, the second highest amino acid contentwas shown by L-aspartic acid (Table 3). Meanwhile, the second major amino acid in black soybean tempeh extract was L-alanine (Table 4). Other amino acid compositions in both tempeh extracts were similar, in which L-histidine was found in least amount.

Amino acid composition predisposes antiphotoaging effect of the peptides. Previous study reported that several amino acid mixtures playedan important role in improving skin collagen synthesis rates in UV-irradiated mice [25]. Branched-chain amino acids (BCAA), which consist of leucine, isoleucine, and valine combined with several amino acids, increased collagen synthesis rates significantly after 30 minutes of oral administration. Our black soybean tempeh peptides contained $18.79 \%$ BCAA, while soybean tempeh peptides contained $15.04 \%$. In addition, glutamic acid, the main amino acid in black soybean (21.18\%) and soybean (23.31\%) tempeh peptides was associated with the stimulation of protein synthesis in vitro and in vivo[26].
Table 3 Amino acid profileof soybean tempeh peptides

\begin{tabular}{ll}
\hline Amino acid standards & $\begin{array}{l}\text { Concentrations } \mathbf{~ g / k g} \\
\text { tempeh powder) }\end{array}$ \\
\hline L-Cystine & 1.345 \\
L-Methionine & 5.934 \\
L-Histidine & 12.509 \\
L-Tyrosine & 13.798 \\
L-Serine & 16.614 \\
L-Threonine & 17.798 \\
L-Isoleucin & 18.265 \\
Glycine & 19.431 \\
L-Phenylalanine & 21.874 \\
L-Valine & 22.832 \\
L-Proline & 25.544 \\
L-Alanine & 26.319 \\
L-Leucine & 26.335 \\
L-Arginine & 28.831 \\
L-Lysin HCl & 34.438 \\
L-Aspartic Acid & 51.843 \\
L-Glutamic Acid & 104.515 \\
\hline
\end{tabular}

Table 4 Amino acid profileof black soybean tempeh peptides

\begin{tabular}{ll}
\hline Amino acid standards & $\begin{array}{l}\text { Concentrations } \mathbf{( g / k g} \\
\text { tempeh powder) }\end{array}$ \\
\hline L-Cystine & 0.920 \\
L-Methionine & 5.901 \\
L-Histidine & 8.793 \\
L-Tyrosine & 10.903 \\
L-Serine & 12.864 \\
L-Arginine & 13.895 \\
L-Threonine & 16.093 \\
L-Isoleucin & 17.453 \\
L-Lysin HCl & 17.493 \\
Glycine & 19.205 \\
L-Proline & 19.874 \\
L-Phenylalanine & 20.326 \\
L-Leucine & 23.388 \\
L-Valine & 29.958 \\
L-Aspartic Acid & 33.738 \\
L-Alanine & 46.178 \\
L-Glutamic Acid & 79.838 \\
\hline
\end{tabular}

Glutamic acid is an amino acid precursor in proline and hydroxyproline collagen formation. It was reported that in collagen biosynthesis, proline was actively derived from glutamic acid in male guinea pig skin [26]. In addition, the total L-amino acids detected were $448.22 \mathrm{~g} / \mathrm{kg}$ and $376.82 \mathrm{~g} / \mathrm{kg}$ dried weight in soybean and black soybean tempeh, respectively. The peptides composed of L-amino acids were reported to protect skin from photoaging and enhance the collagen formation, thus reduced the wrinkles while applied as topical supplementation [27].

\subsection{Effect of Tempeh Peptide Extracts on Skin} Histology Alteration in UVB-treated Mice

In histological staining, normal skin was characterized byorganized structure of epidermisand dermis (Figure 1 A). Moreover, normal skin would show active growth of hair follicles and neurons (Figure 1A), while in photoaging skin hair follicle and sub dermis necrosis 
would be observed (Figure 1B). The disruption of skin structure involved collagen fiber damages due toUVB radiation [28]. Additionally, photoaging skin is characterized by increase of elastosis and fragmentation of collagen beneath the dermalepidermal junction [29]. Commercial cosmeceuticals would protect the skin from radiation as characterized by active growth of hair follicles, active neurons, and reduction of dermal-epidermal junction (Figure 1C). In PP100 group, UVB radiation did not affect the formation of hair follicles and repressed the formation of dermal-epidermal junction (Figure 1D). The epidermis thickened was diminished and the hair follicles were reactivated in accordance with dermis layer attenuation in PP300 group (Figure 1E). Similarly, reduced epidermal thickness was reported after the supplementation of soybean and Haematococcus extracts combination against photoaging in vivo[30].

Supplementation of black soybean tempeh peptidesin varying doses resulted in histological difference according to nominal scoring. HP100 supplementation could not inhibit the increase of the dermal-epidermal junction and hair follicle degeneration (Figure 1F). Furthermore, the adipose tissue of the skin was thickened in this group, suggesting further photoaging alteration in skin structure [31]. In contrast, HP300 prevented photoaging, as shown by reduction ofepidermisdermis junction thickening, organized subdermis structure and hair follicle growth (Figure 1G).

\subsection{Effect of Tempeh Peptide Extracts on Down- regulating Matrix Metalloproteinase-3 and Inflammatory Genes in UVB-induced Mice}

Since the histological staining showed significant changes in epidermis formation, we hypothesized that anti-photoaging agents may work through theenzyme inhibitor mechanism of collagenases. These mechanisms can be detected using several biomarkers, such as genes that encode for MMP-1 that initiates the degradation of type I and III collagen, MMP-3 that degrades type IV collagen, and MMP-9 that further decomposes collagen fragments [32]. Our results showed the UVB-treated mice supplemented with both soybean and black soybean tempeh peptide extractshad down regulation ofMMP-3 gene significantly (Figure 2A). In line with our histological examination, the inhibition level of MMP-3 expression by tempeh peptides was higher than UVB-treated PC group by 3.49 fold to PP100, 3.12 fold to PP300, and 4.45 fold to HP300 respectively. Our further examination to MMP-1 and MMP-9 genes showed no significant difference for these genes expression after tempeh peptide supplementation compared to the UVB-treated control (Figures $2 \mathrm{~B}$ and $2 \mathrm{C}$ ). This phenomenon may correlated with another activation pathway from MMP promoters directly that allows degradation of type I and III collagens [33]. Repression of MMPs inhibitory activity was also recently reported in UVtreated human Hs68 epidermal fibroblast cells supplemented with myristoyl tetrapeptide Gly-LeuPhe-Trp (mGLFW) [34].

In addition, the measurement of inflammation-

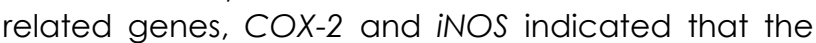
COX-2 and iNOS biomarker trends were in line with the histological examination although no significant differences were obtained (Figures 2D and 2E).The expression of inflammation-related genes, such as interleukin-1 $\alpha$ (IL-1 $\alpha)$, IL6, IL-8, IL-10, tumor-necrosis factor $\alpha$, and proliferator-activated receptor gamma were reported to be abrogated after supplementation of photoaging candidates as one of the hallmark on skin protection [34, 35].

Exposure of UVB radiation led to the upregulation of MMP-encoding genes. It was reported that peptide supplementation of gelatin hydrolysate from pacific cod skin could reduce photoaging effects by inhibiting the expression of MMP-encoding genes and their corresponding proteins [28]. This mechanism is related to UV-irradiation-dependent up-regulated phosphorylation in mitogen-activated protein kinase (MAPK) signaling pathway. Moreover, MMP-9 was secreted by inflammatory cells and activated tumor-associated macrophages, which induced the expression of COX-2 [33]. Repression of COX-2 and iNOS expressions showed the antiinflammatory properties of tempeh peptide extracts. Another study also demonstrated the increase of p38 kinase, extracellular signal-regulated kinase, c-Jun amino-terminal kinase, and c-Jun phosphorylation in UVB-induced mice supplemented with fermented soybean [36].

Tempeh may be a profitable source of peptides with cosmeceutical properties, as it is a common food product which produces at relatively low cost. Although soybean is the most common ingredient in tempeh making, almost any kind of beans can be fermented using the tempeh starter mold Rhizopus microspores [37]. However, more studies should be conducted to evaluate the cosmeceutical potential of tempeh made with various types of ingredients. Our recent study showed that black soybean tempeh was high in antioxidant activity due to the anthocyanin content in black soybeanhulls [38]. Antioxidants play a role in scavenging ROS in the event of skin exposure to UVB radiation, which consequently prevents collagen degradation [29]. Therefore, such activity will lead to the reduction of skin wrinkling and aging due to UVB radiation. 

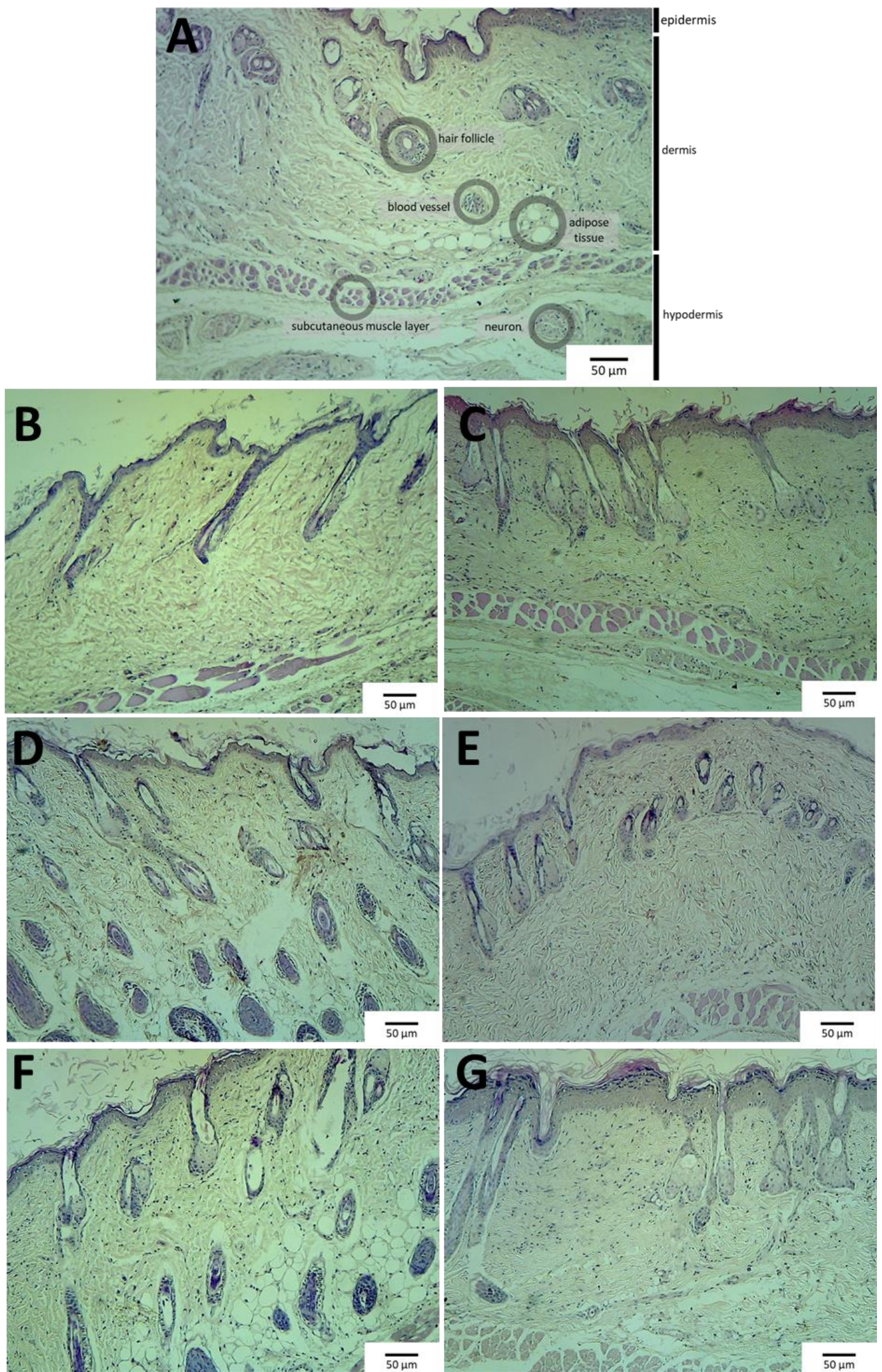

Figure 1 Representative histological changes inmice dorsal skin following photoaging treatment for 4 weeks. The treatment groups were (A) non-UVB-treated mice (NC), (B) positive control UVB-treated mice (PC), (C)UVB-treated mice supplemented by $2 \%$ w/V commercial cosmeceuticals (SP), (D) UVB-treated mice supplemented with $100 \mathrm{mg} / \mathrm{kgs}$ body weight (bw) soybean tempeh peptide (PP100), (E) $300 \mathrm{mg} / \mathrm{kgs}$ bw soybean tempeh peptide (PP300), (F) $100 \mathrm{mg} / \mathrm{kgs}$ bw black soybean tempeh peptide (HP100), and (G) $300 \mathrm{mg} / \mathrm{kgs}$ bw black soybean tempeh peptide (HP300) 

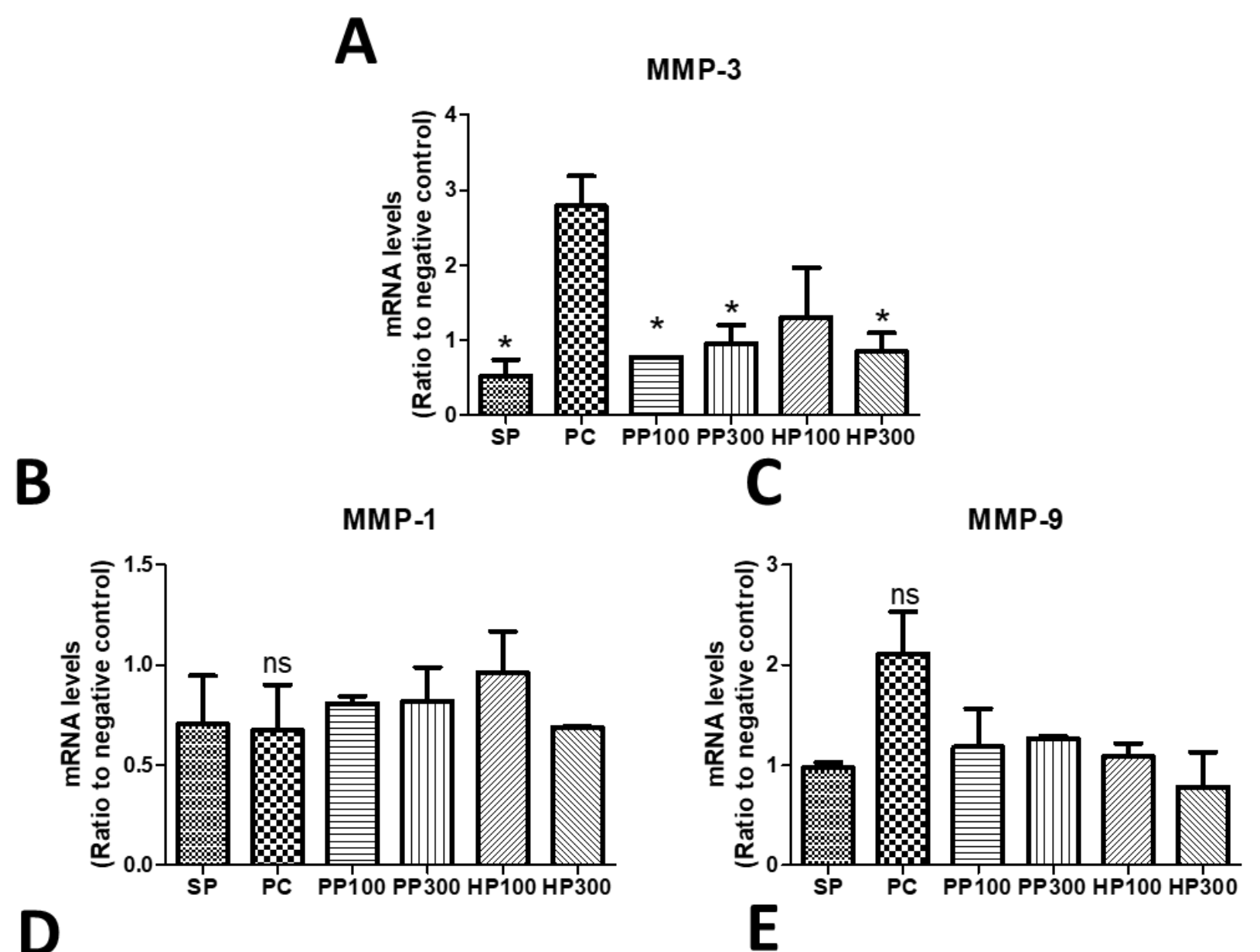

COX-2
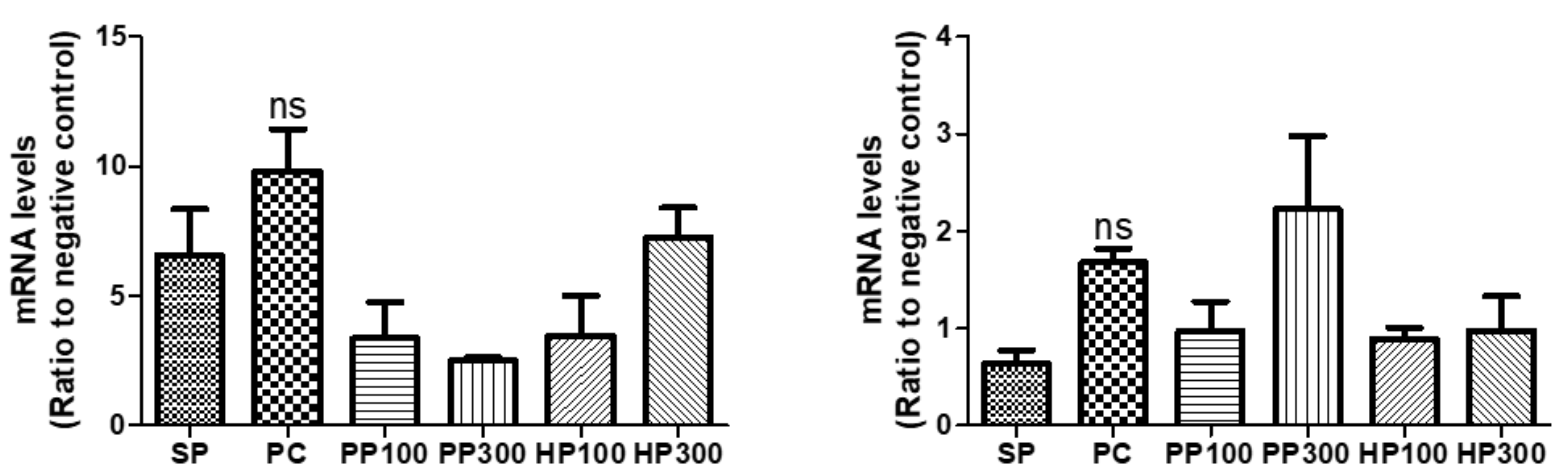

Figure 2 Effect of tempeh peptide extracts on MMP-3 (A), MMP-1 (B), MMP-9 (C), COX-2 (D), and iNOS (E) mRNA expression in mouse skin. The treatment groups were UVB-treated mice supplemented by $2 \% \mathrm{w} / \mathrm{V}$ commercial cosmeceuticals (SP), positive control UVB-treated mice (PC), UVB-treated mice supplemented with $100 \mathrm{mg} / \mathrm{kgs}$ body weight (bw) soybean tempeh peptide (PP100), $300 \mathrm{mg} / \mathrm{kgs}$ bw soybean tempeh peptide (PP300), $100 \mathrm{mg} / \mathrm{kgs}$ bw black soybean tempeh peptide (HP100), and 300 $\mathrm{mg} / \mathrm{kgs}$ bw black soybean tempeh peptide (HP300). Data were shown as mean \pm SD from duplicate experiments. Asterisks (*) indicate significant differences $(\mathrm{P} \leq 0.05)$ compared to $\mathrm{PC}$

\subsection{CONCLUSION}

The present study demonstrated the effectiveness of soybean and black soybean tempeh peptide extractsin reducing photoaging effects in mice, as characterized by the significant down-regulation of
MMP-3and inflammation biomarkers-encoding genes. Here, we confirmed the potential use of tempeh peptide extracts as anti-photoaging cosmeceuticals. Further study is needed to reveal the cosmeceutical mechanisms of soybean and black soybean tempeh peptides, presumably via the MAPK 
pathway, and to formulate products for commercialization purposes.

\section{Acknowledgment}

This research was fully supported by Atma Jaya Research and Community Service Center through Competitive Research Grant (2016) and Faculty of Biotechnology, Atma Jaya Catholic University of Indonesia through Faculty Research Grant (2017).

\section{References}

[1] Mukherjee, S., A. Date, V. Patravale, H. C. Korting, A. Roeder, and G. Weindl. 2006. Retinoids in the Treatment of Skin Aging: An Overview of Clinical Efficacy and Safety. Clinical Interventions in Aging. 1 (4): 327-348.

DOI: https://doi.org/10.2147/ciia.2006.1.4.327.

[2] Park, K., and J. H. Lee. 2008. Protective Effects of Resveratrol on UVB Irradiated HaCaTCells through Attenuation of the Caspase Pathway. Oncology Reports. 19(2): 413-417.

DOI: https://doi.org/10.3892/or.19.2.413.

[3] Nichols, J. A., and S. K. Katiyar. 2010. Skin Photoprotection by Natural Polyphenols: Anti-Inflammatory, Antioxidants and DNA Repair Mechanisms. Archives of Dermatological Research. 302(2): 71-83.

DOI: https://doi.org/10.1007/s00403-009-1001-3.

[4] Pandel, R., B. Poljsak, A. Godic, and R. Dahmane. 2013. Skin Photoaging and the Role of Antioxidants in Its Prevention. International Scholarly Research Notices Dermatology. 2013: 930164. DOI: http://dx.doi.org/10.1155/2013/930164.

[5] Awad, F., et al. 2018. Photoaging and Skin Cancer: Is the Inflammasome the Missing Link? Mechanisms of Ageing and Development. 172: 131-137.

DOI: https://doi.org/10.1016/j.mad.2018.03.003.

[6] Narendhirakannan, R. T., and M. A. C. Hannah. 2013. Oxidative Stress and Skin Cancer: An Overview. Indian Journal of Clinical Biochemistry. 28(2): 110-115. DOI: https://doi.org/10.1007/s12291-012-0278-8.

[7] Pyun, H. B., M. Kim, J. Park, Y. Sakai, N. Numata, J. Y. Shin et al. 2012. Effects of Collagen Tripeptide Supplement on Photoaging and Epidermal Skin Barrier in UVB-exposed Hairless Mice. Preventive Nutrition and Food Science. 17(4): 245-253.

DOI: https://doi.org/10.3746/pnf.2012.17.4.245

[8] Ebner, J., M. Fedorova, A. A. Arslan, and M. Pischetsrieder. 2015. Peptide Profiling of Bovine Kefir Reveals 236 Unique Peptides Released From Caseins During Its Production by Starter Culture or Kefir Grains. Journal of Proteomics. 18(117): 41-57.

DOI: https://doi.org/10.1016/j.jprot.2015.01.005

[9] Kwon, O. W., R. Venkatesan, M. H. Do, E. H. Ji, D. W. Cho, K. W. Lee, et al. 2014. Dietary Supplementation with a Fermented Barley and Soybean Mixture Attenuates UVBinduced Skin Aging and Dehydration in Hairless Mouse Skin. Food Science and Biotechnology. 24(2): 705-715. DOI: https://doi.org/10.1007/s10068-015-0092-1.

[10] Papadimitriou, C. G., A. Vafopoulou-Mastrojiannakia, S. V. Silvab, A. Gomesb, F. X. Malcatab, and E. Alichanidisa. 2007. Identification of Peptides in Traditional and Probiotic Sheep Milk Yoghurt with Angiotensin I-Converting Enzyme (ACE)-Inhibitory Activity. Food Chemistry. 105(2): 647-656. DOI: https://doi.org/10.1016/j.foodchem.2007.04.028.

[11] Boogers, I., et al. 2008. Ultra-performance Liquid Chromatographic Analysis of Amino Acids in Protein Hydrolysates Using an Automated Pre-column
Derivatisation Method. Journal of Chromatography $A$. 1189(1): 406-409.

DOI: https://doi.org/10.1016/j.chroma.2007.11.052.

[12] Kim, H. N., et al. 2016. Anti-photoaging Properties of the Phosphodiesterase 3 Inhibitor Cilostazol in Ultraviolet BIrradiated Hairless Mice. Scientific Reports. 6(1): 31169. DOI: https://doi.org/10.1038/srep31169.

[13] Fischer, A. H., K. A. Jacobson, J. Rose, and R. Zeller. 2008. Hematoxylin and Eosin Staining of Tissue and Cell Sections. Cold Spring Harbor Protocols. 4986. DOI: https://doi.org/10.1101/pdb.prot4986.

[14] Gibson-Corley, K. N.,Olivier A. K., and. Meyerholz, D. K. 2013. Principles for Valid Histopathologic Scoring in Research. Veterinary Pathology. 50(6): 1007-1015. DOI: https://doi.org/10.1177/0300985813485099.

[15] Zhang, L., Y. Zheng, X. Cheng, M. Meng, Y, Luo, and B. Li. 2017. The Anti-photoaging Effect of Antioxidant Collagen Peptides from Silver Carp (Hypophthalmichthys molitrix) Skin is Preferable to Tea Polyphenols and Casein Peptides. Food \& Function. 8(4): 1698-1707. DOI: https://doi.org/10.1039/c6fo01499b.

[16] Sun, L. P., Y. F. Zhang, and Y. L. Zhuang. 2013. Antiphotoaging Effect and Purification of an Antioxidant Peptide from Tilapia (Oreochromis niloticus) Gelatin Peptides. Journal of Functional Foods. 5(1): 154-162. DOI: https://doi.org/10.1016/j.jff.2012.09.006.

[17] Venkatesan, J., S. Anil, S. K. Kim, and M. S. Shim. 2017. Marine Fish Proteins and Peptides for Cosmeceuticals: A Review. Marine Drugs. 15(5): 143. DOI: https://doi.org/10.3390/md15050143.

[18] Petruk, G., R. Del Giudice, M. M. Rigano, and D. M. Monti. 2018. Antioxidants from Plants Protect against Skin Photoaging. Oxidative Medicine and Cellular Longevity. 2018: 1454936. DOI: https://doi.org/10.1155/2018/1454936.

[19] Bosch, R., N. Philips, J. A. Suárez-Pérez, A. Juarranz, A. Devmurari, J. Chalensouk-Khaosaat, and S. González. 2015. Mechanisms of Photoaging and Cutaneous Photocarcinogenesis, and Photoprotective Strategies with Phytochemicals. Antioxidants (Basel). 4(2): 248-268. DOI: https://doi.org/10.3390/antiox4020248.

[20] Ngo, D. H., T. S. Vo, D. N. Ngo, I. Wijesekara, and S. K. Kim. 2012. Biological Activities and Potential Health Benefits of Bioactive Peptides Derived from Marine Organisms. International Journal of Biological Macromolecules. 51 (4): 378-383.

DOI: https://doi.org/10.1016/j.ijbiomac.2012.06.001.

[21] Kim, M. M., Q. V. Ta, E.Mendis, N. Rajapakse, W. K. Jung, H. G. Byun, et al. 2006. Phlorotanninsin Ecklonia Cava Extract Inhibit Matrix Metalloproteinase Activity. Life Sciences. 79(15): 1436-1443. DOI: https://doi.org/10.1016/j.lfs.2006.04.022.

[22] Schurink, M., W. J. van Berkel, H. J. Wichers, and C. G. Boeriu. 2007. Novel Peptides with Tyrosinase Inhibitory Activity. Peptides. 28(3): 485-495. DOI: https://doi.org/10.1016/j.peptides.2006.11.023.

[23] Kim, J. A. and S. K. Kim. 2013. Bioactive Peptides from Marine Sources as Potential Anti-inflammatory Therapeutics. Current Protein and Peptide Science. 14(3): 177-182. DOI: https://doi.org/10.2174/13892037113149990039.

[24] Choi, Y. L., E. J. Park,E. J. Kim, D. H. Na, and Y. H. Shin. 2014. Dermal Stability and In Vitro Skin Permeation of Collagen Pentapeptides (KTTKS and Palmitoyl-KTTKS). Biomolecules and Therapeutics. 22(4): 321-327. DOI: https://doi.org/10.4062/biomolther.2014.053.

[25] Murakami, H., K. Shimbo,Y. Inove, Y.Takino, and H. Kobayashi. 2012. Importance of Amino Acid Composition to Improve Skin Collagen Protein Synthesis Rates in UVIrradiated Mice. Amino Acids. 42(6):2481-2489. DOI: https://doi.org/10.1007/s00726-01 1-1059-z.

[26] Ishibashi, S., T. Ide, and S. Tsurufuji. 1968. Role of Glutamic Acid as a Precursor of Collagen Proline and 
Hydroxyproline. Biochimica et Biophysica Acta. 165(2): 296-299.

DOl: https://doi.org/10.1016/0304-4165(68)90061-5.

[27] Hou, H., B. Li, X. Zhao, Y. Zhuang, G. Ren, M. Yan, Y. Cai, X. Zhang, and L. Chen. 2009. The Effect of Pacific Cod (Gadus macrocephalus) Skin Gelatin Polypeptides on UV Radiation-induced Skin Photoaging in ICR Mice. Food Chemistry. 115(3): 945-950.

DOI: https://doi.org/10.1016/j.foodchem.2009.01.015.

[28] Chen, T. J., H. Hou, Y. Fan, S. Wang, Q. Chen, L. Si, et al. 2016. Protective Effect of Gelatin Peptides from Pacific Cod Skin against Photoaging by Inhibiting the Expression of MMPs via MAPK Signaling Pathway. Journal of Photochemistry and Photobiology. 165: 34-41. DOI: https://doi.org/10.1016/j.jphotobiol.2016.10.015.

[29] Poon, F., S. Kang, and A. L. Chien. 2015. Mechanisms and Treatments of Photoaging. Photodermatology, Photoimmunology \& Photomedicine. 31 (2): 65-74. DOI: https://doi.org/10.1111/phpp.12145.

[30] Shin, J., J. E. Kim, K. J. Pak. J. I. Kim, S. Y. Lee, I. H. Yeo, et al. 2017. A Combination of Soybean and Haematococcus Extract Alleviates Ultraviolet B-induced Photoaging. International Journal of Molecular Sciences. 18(3):1-13. DOI: https://doi.org/10.3390/ijms18030682.

[31] Rittié, L. and G. J. Fisher. 2015. Natural and Sun-induced Aging of Human Skin. Cold Spring Harbor Perspectives in Medicine. 5(1): 1-14.

DOI: https://doi.org/10.1101/cshperspect.a015370.

[32] Kahari, V. M. and U. Saarialho-Kere. 1997. Matrix Metalloproteinases in Skin. Experimental Dermatology. 6(5): 199-213.

DOI: https://doi.org/10.1111/j.1600-0625.1997.tb00164.x.
[33] Pittayapruek, P., J. Meephansan, O. Prapapan, M. Komine, and M. Ohtsuki. 2016. Role of Matrix Metalloproteinases in Photoaging and Photocarcinogenesis. International Journal of Molecular Sciences. 17(6): 868. DOI: https://doi.org/10.3390/ijms17060868.

[34] Kwon, H., E. Ahn, S. Y. Kim, Y. Kang, M. O. Kim, B. S. Jin, et al. 2016. Inhibition of UV-induced Matrix Metabolism by AMyristoylTetrapeptide. Cell Biology International. 40(3): 257-268.

DOI: https://doi.org/10.1002/cbin.10557.

[35] Kim, J. M., S. Y. Kim, E. M. Noh, H. K. Song, G. S. Lee, K. B. Kwon, et al. 2018. Reversinelnhibits MMP-1 and MMP-3 Expressions by Suppressing of ROS/MAPK/AP-1 Activation in UV-stimulated Human Keratinocytes and Dermal Fibroblasts. Experimental Dermatology. 27 (3): 298-301. DOI: https://doi.org/10.1111/exd.13494.

[36] Lee, T. H., M. H. Do,Y. L. Oh, D. W. Cho, S. H. Kim, and S. Y. Kim. 2014. Dietary Fermented Soybean Suppresses UVBInduced Skin Inflammation in Hairless Mice via Regulation of the MAPK Signaling Pathway. Journal of Agricultural and Food Chemistry. 62(36): 8962-8972. DOI: https://doi.org/10.1021/jf5018252.

[37] Hartanti, A. T., G. Rahayu, and I. Hidayat. 2015. RhizopusSpecies from Fresh Tempeh Collected from Several Regions in Indonesia. Hayati Journal of Biosciences. 22(3): 136-142.

DOI: https://doi.org/10.1016/j.hjb.2015.10.004.

[38] Ghosh, D. and T. Konishi. 2007. Anthocyanins and Anthocyanin-rich Extracts: Role in Diabetes and Eye Function. Asia Pacific Journal of Clinical Nutrition. 16(2): 200-208.

DOI: https://doi.org/10.6133/apjcn.2007.16.2.01. 